\title{
Working
}

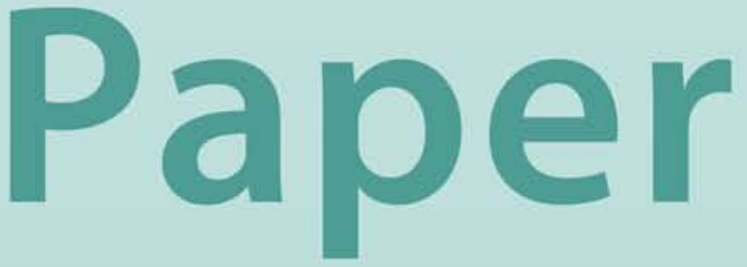


Political Budget Cycles in Papua New Guinea

Ebrima Faal 


\title{
IMF Working Paper
}

Asia and Pacific Department

\section{Political Budget Cycles in Papua New Guinea}

\author{
Prepared by Ebrima Faal ${ }^{1}$
}

Authorized for distribution by Milan Zavadjli

September 2007

\begin{abstract}
This Working Paper should not be reported as representing the views of the IMF. The views expressed in this Working Paper are those of the author(s) and do not necessarily represent those of the IMF or IMF policy. Working Papers describe research in progress by the author(s) and are published to elicit comments and to further debate.

This paper assesses the presence of opportunistic electoral budget cycles in Papua New Guinea. Using quarterly time series data, a clear pattern emerges of pre-election manipulations of fiscal policy by incumbent governments, mainly in the form of increased development spending and overall primary expenditure, followed in some cases by retrenchment in post-election periods. These findings are consistent with the predictions of rational opportunistic political business cycle theory. It is noteworthy that revenue was not statistically significantly related to elections, either in the pre- or post-election period. In this regard, electoral swings in fiscal deficits reflect a preference for influencing expenditures rather than taxation.

JEL Classification Numbers:E32, O23, N17, P16

Keywords: Economic cycles, Fiscal policy, Politics, Papua New Guinea

Author's E-Mail Address: efaal@,imf.org

\footnotetext{
${ }^{1}$ This paper received insightful comments from Susan Creane, Milan Zavajli, and Professor Edward (Ted) Wolfers. I am also grateful to other colleagues and participants at seminars held at the Bank of Papua New Guinea and Department of Treasury and Finance (Papua New Guinea) for helpful conversations and comments. Any errors or omissions are those of the author.
} 


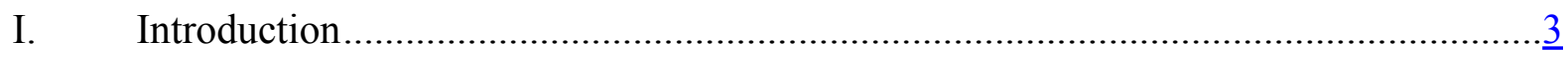

II. Theoretical and Empirical Considerations .....................................................

III. Papua New Guinea's Political System.............................................................

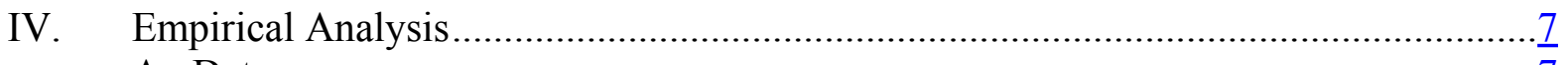

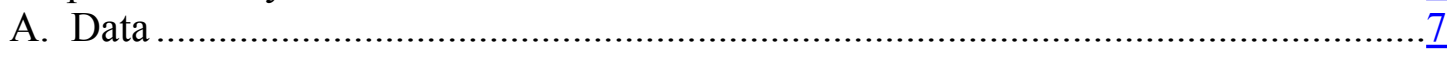

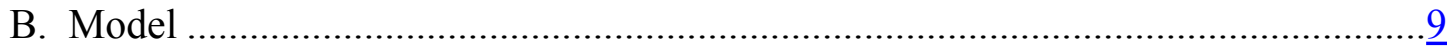

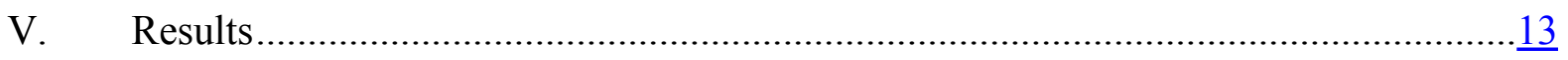

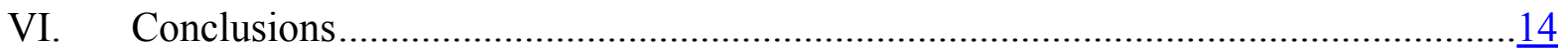

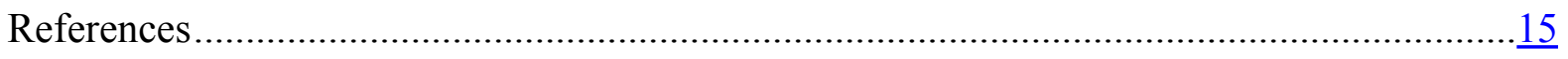




\section{INTRODUCTION}

The political budget cycle literature argues that incumbent governments may use expansionary economic policies prior to elections to influence voters and maximize chances of re-election. ${ }^{2}$ In the political economy literature, this outcome is known as the political business cycle, that is, a macroeconomic cycle induced by the political cycle. Empirical testing of competing models supporting the theory has relied mostly on data from the industrial democracies, where results have been mixed. To date, there have been few tests of political business cycle theory in developing countries, and none with significant reference to Papua New Guinea. ${ }^{3}$

Several factors point to the existence of political budget cycles in Papua New Guinea. Anecdotal evidence suggests pre-election periods have seen increases in social welfare transfers and capital spending, and a rapid liquidation of public sector arrears and increase in public debt. In addition, Papua New Guinea, as many other developing countries, has relatively weak institutions. As a result, there are relatively few constraints on government actions and accountability.

This paper examines and tests the existence of political budget cycles in Papua New Guinea during the period 1988-2004. Section II provides an overview of the political business cycle literature. Section III provides an overview of Papua New Guinea's political structure and processes. Section IV describes the data set and the empirical methods used to test for the presence of election-influenced spending, and presents the results of a time series analysis. Section V details the paper's conclusion.

\section{TheoretiCAL AND EMPIRICAL CONSIDERATIONS}

Two main bodies of literature (opportunistic and partisan) explore economic fluctuations around elections. The literature on opportunistic budget cycles argues that electoral pressures force the incumbent party to manipulate economic policy in order to increase the probability of re-election. Partisan theory argues that policies are predetermined by ideology.

Specifically, left-wing parties are concerned more with unemployment than inflation, the inverse of right-wing parties. As a result, economic fluctuations arise from the policy changes that different parties pursue while in office. ${ }^{4}$

The first opportunistic political business cycle models and were based on the premise that voters are myopic. ${ }^{5}$ Nordhaus argued that politicians are able to repeatedly fool voters, even though voters may already have formed a view on the outcome of upcoming elections. This

${ }^{2}$ Drazen (2001) provides a good survey of political business cycles.

${ }^{3}$ Shi and Svensson (2000), Moyo (1999), and Khemani (2004).

${ }^{4}$ See Hibbs (1977), Frey and Schneider (1978), and Alesina (1987). 
was seen as independent of the ideology of the party in power and was explained by faster rates of real growth and/or higher inflation rates in the period leading into each election. More recent models of the political business cycle (for example, Rogoff and Sibert, 1988, and Rogoff, 1990) have abandoned this assumption in favor of the "Lucas critique" (1976). The Lucas critique posits that economic actors form rational expectations by optimally using all available information to forecast the future.

These newer models substitute an assumption of asymmetric information for voter myopia by assuming that voters do not have full information about incumbents' competence. Voters want to elect the most competent politicians and form rational expectations regarding the incumbent's abilities based on observable current fiscal policy outcomes. Before the election, incumbents with a high probability of success will attempt to signal their competence (and thereby increase their chances of re-election) by engaging in expansionary fiscal policy. This leads to a pre-election increase in the government deficit even though competent politicians may be in office. Rogoff (1990) specifically argues that incumbents can signal their competence before an election by shifting government expenditure towards easily observed consumption spending and away from investment. The key distinction between the predictions of the rational and those of the naïve opportunistic theories, therefore, is that the former relate explicitly to manipulation of fiscal instruments rather than direct macroeconomic outcomes.

Empirical support of the political business cycle theory is mixed. Studies of developed countries (Alesina and Sachs, 1988; Alesina and Roubini, 1988) reveal much stronger evidence of partisan rather than opportunistic cycles. The weak evidence for opportunistic cycles in developed countries then motivated a wave of empirical research to examine whether such cycles occur in developing countries. There, the research produced more convincing evidence of opportunistic cycles. Ames (1987) found evidence of increased public spending in Latin America. In a time series study focusing on Cameroon, Ames (1987) identified evidence of electoral cycles in monetary growth. Khemani (2004) found evidence of electoral-timed cycles in commodity taxes, road construction, and capital spending, in a time series study of India. Other studies have identified electoral competition (Block, 2001), and levels of democracy and transparency (Gonzalez 2002), as important determinants of political business cycles.

\section{Papua New Guinea’s Political System}

Papua New Guinea is the second-largest country in Oceania in terms of population and third in terms of land area. ${ }^{6}$ The country is endowed with a rich natural resource base, which includes major gold and copper deposits, large oil and natural gas reserves, and extensive

\footnotetext{
${ }^{5}$ Developed by Nordhaus (1975) and Lindbeck (1976).

${ }^{6}$ The exact scope of Oceania is defined variously, with interpretations including Australia, New Zealand, New Guinea, and various islands of the Malay Archipelago.
} 
forests and maritime fisheries. Yet, despite this abundant source of wealth, Papua New Guinea still struggles to achieve sustained economic growth. Throughout its post-colonial history, it has been periodically beset by periods of severe economic crisis.

Papua New Guinea has a unicameral Westminster-style national parliament. The Parliament is composed of 109 members elected from a two-tier system composed of 89 "open" electorates of approximately equal population size and 20 "regional" electorates based on the boundaries of the country's 19 provinces and its National Capital District. The parliamentary term is five years. National elections began in1964; the most recent was held in June 2002. Two different electoral systems have been used. Between 1975 and 2002, a plurality, firstpast-the-post system was followed, with winners frequently gaining less than 15 percent of the vote. Electoral reforms in 2001 introduced the Limited Preferential Vote system, a version of the alternative vote system used for single winner elections in which voters rank candidates in order of preference. The first general election to be conducted using the new system will be held in 2007.

Politics in Papua New Guinea have been marked by three distinct features, the first being that Papua New Guinea has an impressive record of democratic longevity in the developing world. $^{7}$ There have been over 40 years of uninterrupted democratic elections at the national level. ${ }^{8}$ Relevant political and social constituencies accept democratic institutions and regard them as legitimate. ${ }^{9}$ There is universal suffrage. Elections have been conducted on time since independence. Transfer of power takes place peacefully on a regular basis. The military and the police have not engaged in active politics. However, while democracy is generally accepted, vote buying, ballot rigging, violence and intimidation, and other forms of irregularity are widespread.

Second, despite the broad acceptance of the legitimacy of democratic institutions, problems of institutional instability have occurred due to the fact that no government since independence in 1975 has lasted its full term. ${ }^{10}$ The average life of a government is less than three years. Government has changed hands ten times since July 1977 . Five changes have come through elections, three by votes of no confidence, and one each through a court ruling and a resignation (Table 1). The constant shifting of parliamentary loyalties meant that no government was safe from a vote of no confidence (other than during the "grace periods" of

\footnotetext{
${ }^{7}$ Reilly (2000) provides an assessment of the political process in Papua New Guinea.

${ }^{8}$ Lijphart (1999) considers Papua New Guinea to be amongst the world's 36 "established" democracies. The first general elections in PNG was in 1964 although the executive became accountable to the legislature only after 1972. Other analysts are less positive; see, for example, the World Bank's Fragile States: The Low Income Countries Under Stress Initiative.

${ }^{9}$ There have been exceptions, including the Bougainville crisis and the 2002 elections in the Southern Highlands.

10 The current Somare (2002-2007) government will be the first to complete a full term in office.
} 
18 months when a new government is formed and 12 months before a general election). ${ }^{11}$ Political personalities and patronage are more important than political parties (see Okole 2004). In most cases, political parties are means for their leaders to achieve personal ambitions, with no ideological underpinnings, or simply a medium to help form a government. This has resulted in a high level of voter volatility.

\begin{tabular}{|c|c|c|c|}
\hline Date & Prime Minister & Deputy Prime Minister & Reason for change \\
\hline $\begin{array}{r}\text { July-77 } \\
\text { March-80 } \\
\text { August-82 } \\
\text { November-85 } \\
\text { July-87 } \\
\text { July-88 } \\
\text { July-92 } \\
\text { August-94 } \\
\text { July-97 } \\
\text { July-99 } \\
\text { August-02 }\end{array}$ & $\begin{array}{l}\text { Michael Somare (Pangu) } \\
\text { Julius Chan (PPP) } \\
\text { Michael Somare (Pangu) } \\
\text { Paias Wingti (PDM } \\
\text { Paias Wingti (PDM) } \\
\text { Rabbie Namaliu (Pangu) } \\
\text { Paias Wingti (PDM) } \\
\text { Julius Chan (PPP) } \\
\text { Bill Skate (PNC) } \\
\text { Mekere Morauta (PDM) } \\
\text { Michael Somare (NA) }\end{array}$ & $\begin{array}{l}\text { Julius Chan (PPP) } \\
\text { lambakey Okuk (NP) } \\
\text { Paias Wingti (Pangu) } \\
\text { Julius Chan (PPP) } \\
\text { Julius Chan (PPP) } \\
\text { Ted Diro (PAP) } \\
\text { Julius Chan (PPP) } \\
\text { Chris Haiveta (Pangu) } \\
\text { Chris Haiveta (Pangu) } \\
\text { John Pundari (PAP) } \\
\text { Allan Marat (PPP) } \\
\text { Sir Moi Avei (MA) } \\
\text { Don Polye NA }\end{array}$ & $\begin{array}{l}\text { National elections } \\
\text { Vote of no confidence } \\
\text { National elections } \\
\text { Vote of no confidence } \\
\text { National elections } \\
\text { Vote of no confidence } \\
\text { National elections } \\
\text { Court ousted PM } \\
\text { National elections } \\
\text { Incumbent PM resigned } \\
\text { National elections }\end{array}$ \\
\hline \multicolumn{4}{|c|}{$\begin{array}{l}\text { Key: Pangu = Pantu Pati; PPP = People's Progress Party; NP = National Party, PDM = People's Democratic } \\
\text { Movement; PAP = People's Action Party; PNC = People's National Congress; NA = National Alliance. } \\
\text { Sources: Henry Okole (2005), and author updates. }\end{array}$} \\
\hline
\end{tabular}

Third, the frequent changes of governments and politics has created a class of politicians and members of parliament who are myopic in their outlook and who, because of the short political cycles, are prone to rent-seeking activities. An important reinforcing factor is the reciprocal relationship between voters and their elected representatives. In general, voters want and demand tangible benefits such as roads, schools, hospitals, etc., while members of parliament want re-election. As Okole (2004) observed: "how these sides hold each other accountable to their respective ends of the bargain is what explains in part the haphazard performance of the legislative body." A simple way to gauge the success of a member of parliament is, very often, by how much he or she brings home to their constituency in the form of tangible services such as schools, roads, and aid posts in rural areas; more recently, this has included personal benefits to individual constituents. As a result, a major preoccupation for members of parliament is to obtain portfolios in the government that allow them to disburse benefits to voters in their own constituencies. From a strategic perspective, therefore, it is advantageous to be in those ranks of the government where control of the public purse confers those benefits that those in the opposition or backbenches do not enjoy

\footnotetext{
${ }^{11}$ From 1975-1992, an incoming government was protected from votes of no confidence for only six months. The term grace period is probably a misnomer since a vote of no confidence passed during the last 12 months would not lead to the replacement of the prime minister, but would instead lead to a general election. Given the reluctance of MPs to go to elections, the provision means that votes of no confidence are never moved or passed during the last 12 months of a government's term.
} 
for their constituents. The concern with immediate material returns from elections is underlined by the introduction, continued existence and importance of members of parliament discretionary funds.

In 2001 the government of Sir Mekere Morauta introduced the Organic Law on the Integrity of Political Parties. This legislation was designed to reduce instability in government. The Integrity Law came into effect after the 2002 national elections. One of its key provisions prohibited members of parliament from switching political parties except under circumstances specified by the Law. Some political developments since 2002 have tested the Integrity Law, though more time is required to determine how effective it will be in easing Papua New Guinea's political issues.

\section{EMpirical ANALYSIS}

\section{A. Data}

Most empirical studies of developing countries have used annual data to conduct analysis of political budget cycles. This means that not all fluctuations can be captured, especially if they are of short duration. Akhmedov and Zhuravskaya (2004) argue that monthly data should be used so as to allow a very careful measurement of even very short cycles. High frequency data enables the model better able to detect fluctuations of short duration and there is now a growing trend toward using monthly or quarterly data to analyze political business cycles. High political instability arising from votes of no confidence and from fragile coalitions in Papua New Guinea during the study period argue for the use of quarterly data (the highest frequency available).

This study therefore uses a data set of quarterly seasonally adjusted fiscal policy indicators covering the sample period 1988:Q1-2004:Q4. The main reason for choosing this period is that quarterly data are readily available only after 1987. The period includes three parliamentary elections and four changes of government arising from votes of no confidence or resignations of the prime minister.

The fiscal data includes central government total revenue, total expenditure, recurrent expenditure, development expenditure, and, net credit to the public sector. For an incumbent government, all the above items are ways of signaling to voters by applying opportunistic policies before elections. Expenditure items of the budget consist mainly of total expenditures, non-interest expenditures, non-interest recurrent expenditures, and development expenditures. ${ }^{12}$ Data on other components of the budget, including transfers, were not readily available and are not considered in this paper. Since the government decides

\footnotetext{
${ }^{12}$ Fiscal data are derived from the Bank of Papua New Guinea's Quarterly Economic Bulletin and Treasury Budget Reports.
} 
the allocation and distribution of expenditures, this, rather than manipulation of revenue, is the more likely channel for implementing opportunistic policies.

In Papua New Guinea, interest expenditure has been a significant component of total expenditure, averaging 13 percent per year during 1988-2004. For this reason, primary expenditure and the primary deficit represent a more appropriate guide for determining fiscal policy. In the regressions, all the fiscal variables are taken as ratios to total expenditure given that the central focus of our analysis is to test the behavior of fiscal variables during election periods.

Table 2 presents a framework for assessing the magnitude of the econometric results. During 1988:Q2-2004:Q4, the average ratio of revenue to expenditure equaled 7.3 percent of GDP with a standard division of 1.08. Overall, expenditure displays significantly more variability, as measured by the standard deviation, than revenue. The primary and fiscal deficits averaged 0.57 and -1.5 percent of GDP per quarter, with the overall deficit displaying significantly more variability than the primary deficit. Stock of net claims on the government is also substantial, averaging 9 percent of GDP per quarter with a standard deviation of 3.13.

\begin{tabular}{|c|c|c|c|c|c|c|c|}
\hline & \multirow[b]{2}{*}{ Revenues } & \multicolumn{3}{|c|}{ Expenditure } & \multicolumn{2}{|c|}{ Deficit } & \multirow{2}{*}{$\begin{array}{r}\text { Net Claims } \\
\text { on government }\end{array}$} \\
\hline & & Recurrent & Development & Primary & Primary & Total & \\
\hline Mean & 7.34 & 5.50 & 1.21 & 8.97 & 0.57 & -1.50 & 9.03 \\
\hline Median & 7.27 & 5.31 & 0.88 & 8.54 & 0.51 & -1.23 & 9.57 \\
\hline Maximum & 10.01 & 8.55 & 4.20 & 17.29 & 3.48 & 1.70 & 15.71 \\
\hline Minimum & 5.63 & 3.35 & 0.17 & 5.21 & -3.50 & -5.96 & 1.98 \\
\hline Std. Dev. & 1.08 & 1.21 & 1.89 & 2.36 & 1.23 & 1.57 & 3.13 \\
\hline Skewness & 0.63 & 0.31 & 1.54 & 0.89 & -0.26 & -0.67 & -0.61 \\
\hline Kurtosis & 2.79 & 2.34 & 5.23 & 4.06 & 3.86 & 3.37 & 3.02 \\
\hline Observations & 65 & 65 & 65 & 65 & 65 & 65 & 65 \\
\hline
\end{tabular}

Several methods are available to separate cyclical and trend movements in macroeconomic variables. The Hodrick-Prescott filter is the most commonly used. It suffers, however, from many weaknesses, including not being able to distinguish between short-term fluctuations, which may be interpreted in terms of the economy (the cycle) and those that cannot be explained by (errors in measurement), and the tendency of this process to deform the dynamic properties of the data by introducing spurious cycles. This paper uses the BaxterKing filter to decompose the macroeconomic time series into three different and uncorrelated frequency components using the ideal band pass filter.

Figures $1-5$ show the trend in the log levels of primary expenditure, primary recurrent expenditure, capital expenditure, net credit to the public sector, and total revenues. In all cases, there are no clear patterns or synchronization between the level of the fiscal variable and elections. However, better synchronization of the cyclical components of the fiscal 
variables with elections is evident in the cyclical component. The remainder of the paper seeks to confirm econometrically if this relationship is significant.

\section{B. Model}

To test the implication of the political budget cycle theory, the following model is estimated:

$$
y_{t}=\alpha+\sum_{j=1}^{n} \beta_{i} y_{i}+\delta_{t} \text { elect }_{k t}+\sum_{i=1}^{n} s_{i}+\varepsilon_{i}
$$

$\mathrm{K}=1,2,3 \ldots 8$.

where $y$ is the policy variable and is assumed to follow an autoregressive process. It is also assumed that this process is interrupted by elections, as captured by the dummy term elect $t_{k}$; $\varepsilon_{t}$ is the error term at time $t ; n$ is the lag order, and is specified by the Schwarz Information Criterion; $k$ is the quarter the dummy represents. The coefficient $\delta_{k}$ of the dummy variable $d_{k t}$ is tested under the null hypothesis $\left(\mathrm{H}_{0}: \delta_{k}=0\right)$.

The dependent variable in each specification is a particular fiscal instrument to be tested for evidence of political cycles. This test is implemented for five fiscal policy variablesprimary expenditure, recurrent primary expenditure, development expenditure, total revenues, and net claims on government. A dummy variable is introduced to reflect the effect of elections. The dummy variable takes the value of 1 in the period when expansionary policies are expected and -1 when the post-election contraction is anticipated.

The estimated model also controls for variations in government expenditure that are due to reasons exogenous to the domestic political cycle. Given the openness of Papua New Guinea's economy and that its political trends have little effect on global economic outcomes, the rate of growth of its external terms of trade is a useful control for the importance of nonpolitical factors that might influence Papua New Guinea's economy. ${ }^{13}$

\footnotetext{
${ }^{13}$ Openness is defined as the sum of exports and imports over GDP. It averaged 98.4 percent of GDP during the 1988 to 2004 period.
} 
Figure 1. Papua New Guinea: Total Primary Expenditure, 1988-2004 1/ (In logarithm)
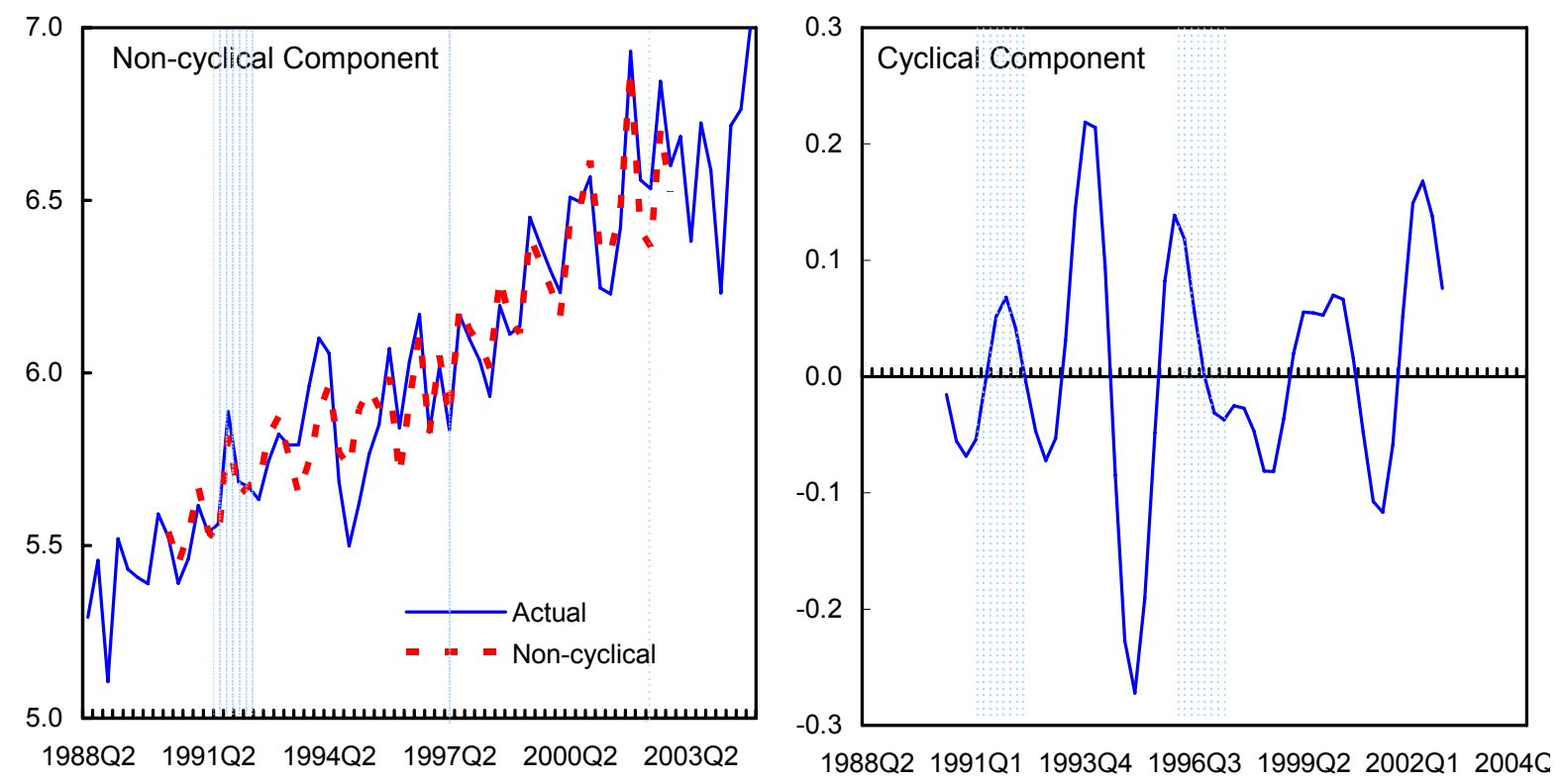

$1 /$ Shaded areas are election periods.

Figure 2. Papua New Guinea: Recurrent Expenditure, 1988 - 2004 1/ (In logarithm)
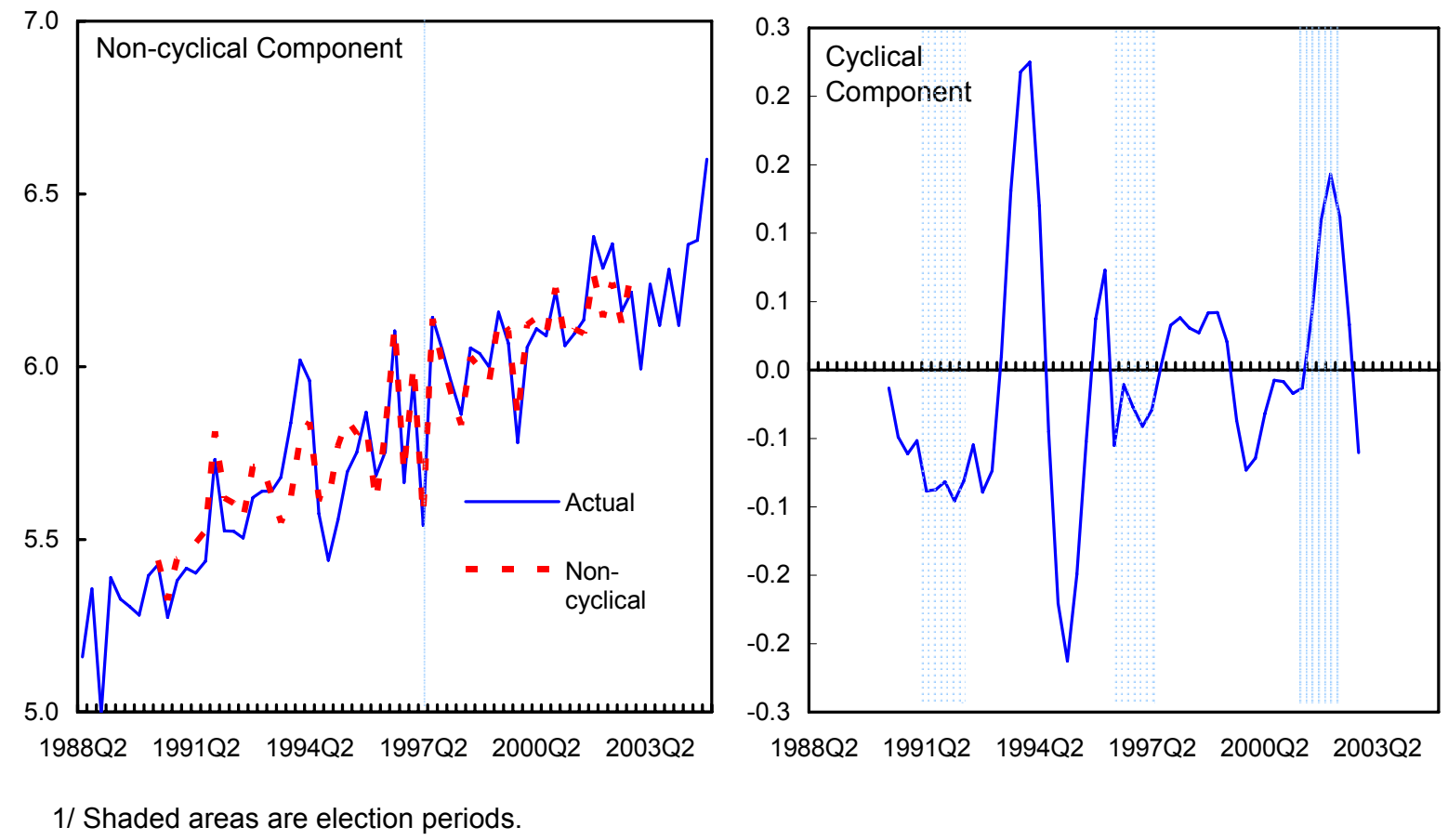

1/ Shaded areas are election periods 
Figure 3. Papua New Guinea: Development Expenditure, 1988-2004 1/ (In logarithm)
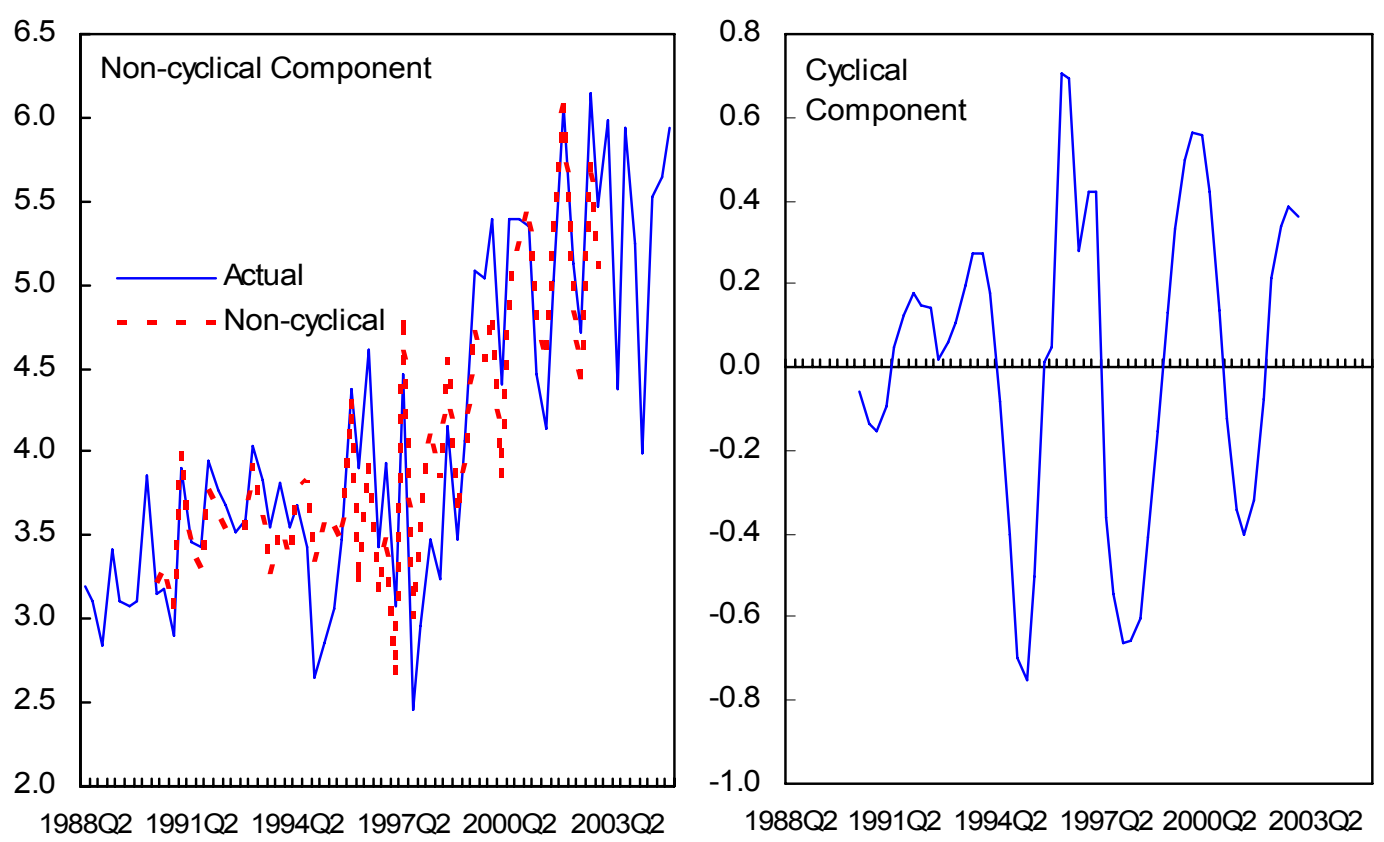

Figure 4. Papua New Guinea: Total Revenues, 1988-2004 1/

(In logarithm)
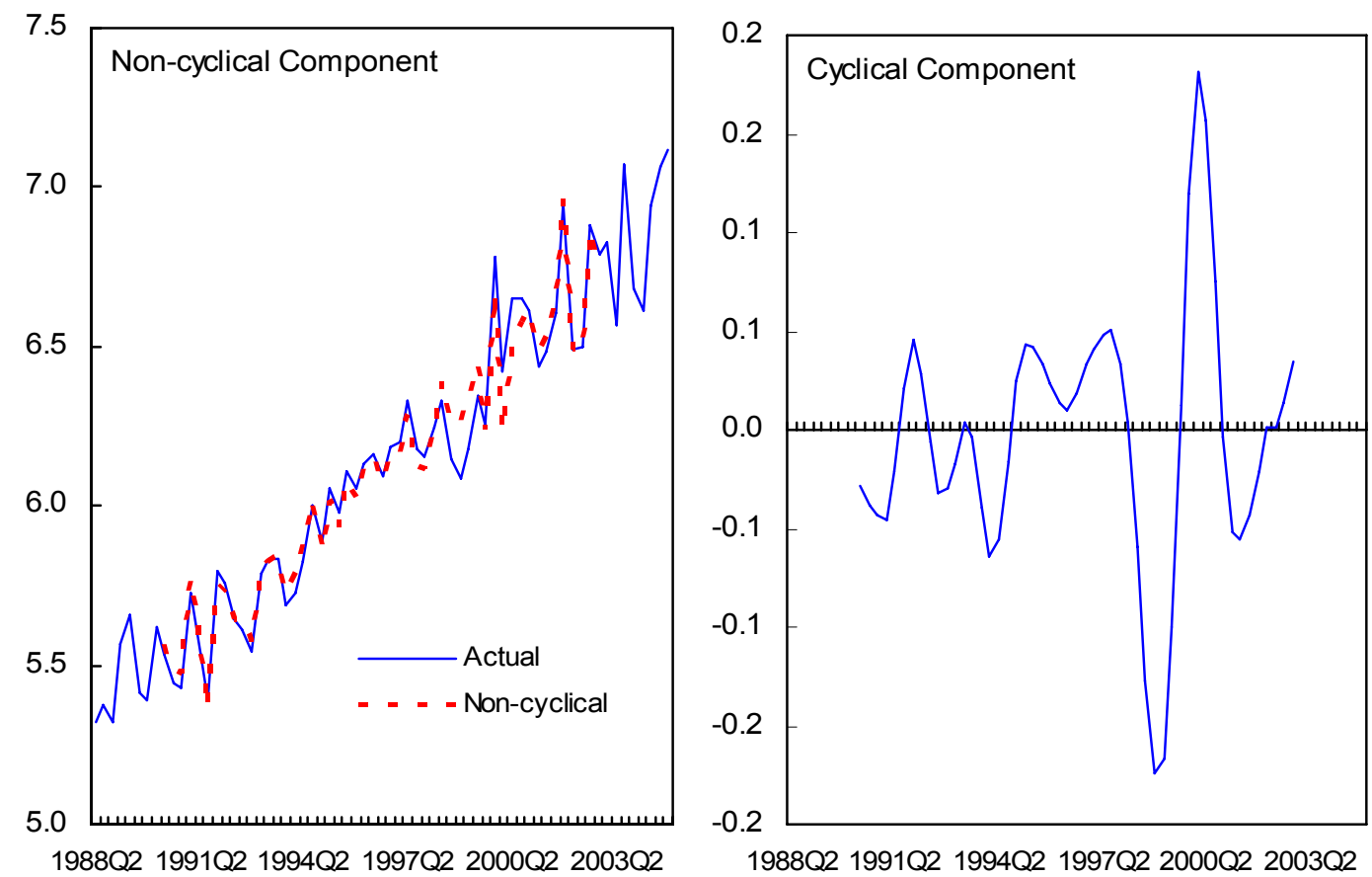

1/ Shaded areas are election periods. 


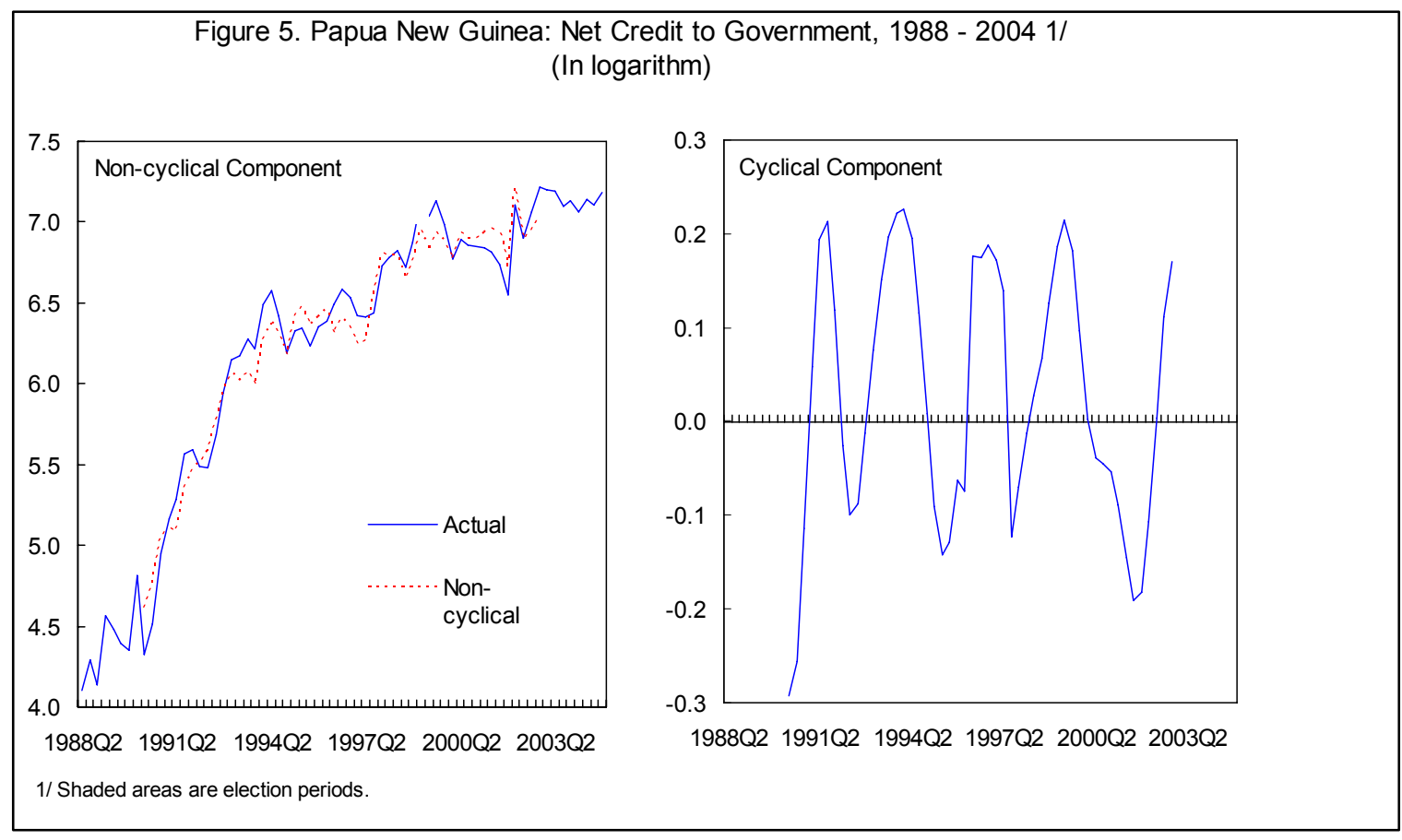

Finally, the analysis accounts for the peculiarities of the parliamentary system of government in Papua New Guinea. Like most parliamentary systems, the party winning power gains control over the government's policy instruments if it wins a simple majority of seats. If the winning party lacks a clear majority and must therefore govern in coalition with other parties, then control over policy instruments is more difficult. In Papua New Guinea, all governments since independence in 1975 have been coalition governments. As a result, the winning party has been forced to moderate its partisan concerns, or at least to accommodate those of its key coalition partners, in order to maintain the "confidence" of the House. In this environment, both policy and political decisions would likely be aberrant. ${ }^{14}$ To account for this, the analysis considers a dummy variable labeled "confidence" to indicate those years when government has changed through a vote of no confidence or other constitutional means outside of a scheduled national election.

\footnotetext{
${ }^{14}$ Kontopolous and Perotti (1999) and Persson, Roland, and Tabellini (2004), for example, use a commonpooling argument to demonstrate higher than normal spending under coalition governments.
} 


\section{Results}

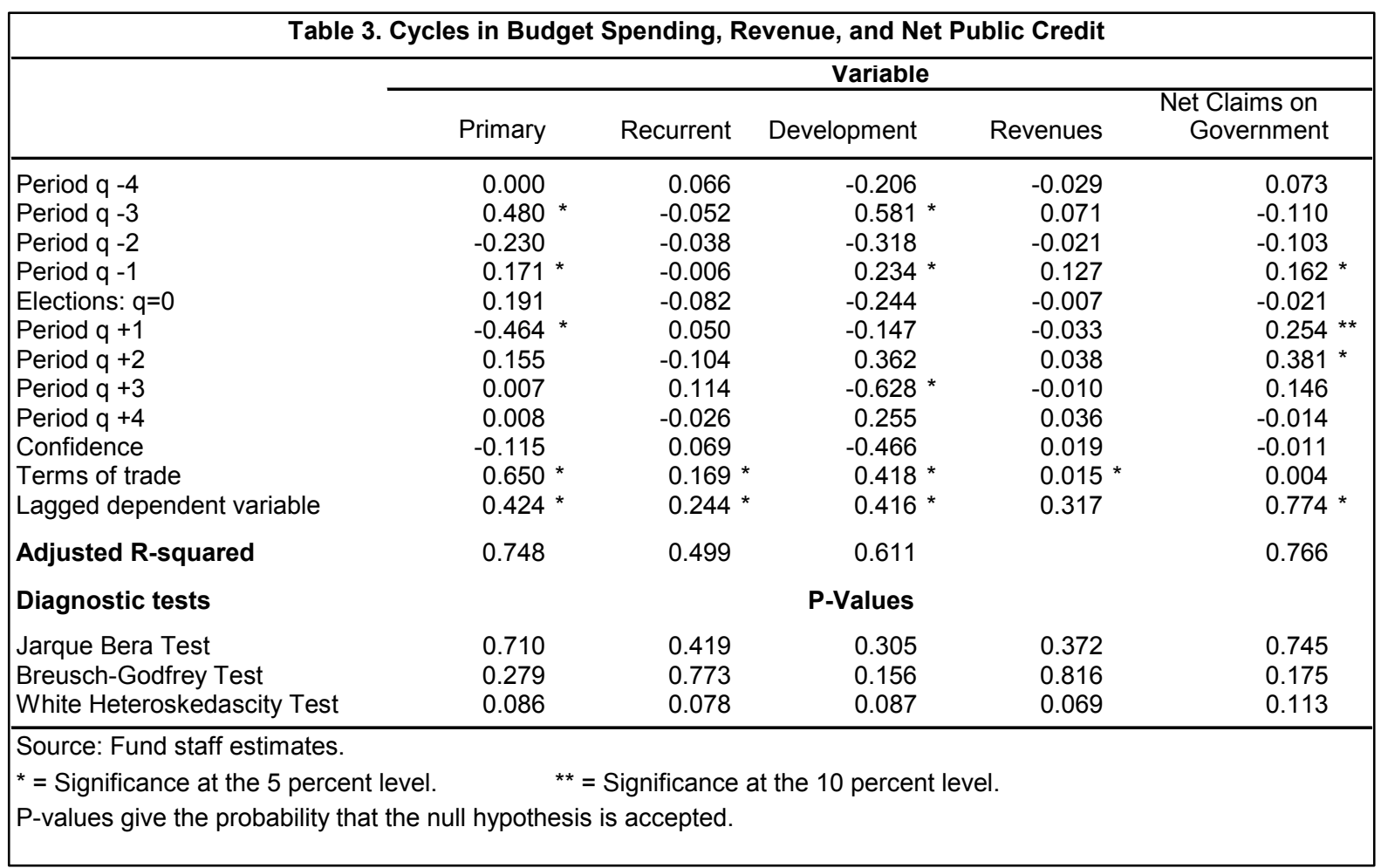

The estimations' results are presented in Table 3. Total primary expenditure experiences the first significant jump of 48 percent three quarters before elections compared with trend. After that, there are no statistically significant changes until the quarter preceding the elections, when expenditure rises by 17 percent. No significant developments take place in the election quarter, but the quarter following the elections is characterized by a statistically significant fall in total primary expenditures of around 46 percent. Development expenditure mimics the pattern seen in total primary expenditures with the exception that a sharp decline in development expenditure of about 68 percent takes place three quarters after the elections. The estimation finds no evidence of budget cycles in primary recurrent expenditures, or any indication that the confidence variable - proxy for coalition governments - affects the political budget cycle in Papua New Guinea. ${ }^{15}$ The lagged dependent variable is statistically significant in all the estimations while the control variable (terms of trade) is statistically significant in all but the estimation of net public credit.

Election-related spending financed in part through domestic borrowing. It is interesting to note that revenue was not statistically significantly related to elections in the pre- or postelection period. Electoral swings in fiscal deficits thus reflect a preference to manipulate

\footnotetext{
${ }^{15}$ Khemani (2004) and Gonzalez (2002) find significant pre-electoral increases in public investment in Mexico and India. In contrast, Block (2002), using an annual panel of developing countries, found that budget composition shifted away from public investment and toward current consumption in the period leading to elections.
} 
expenditure rather than taxation. ${ }^{16}$ Given these findings, how did governments finance election-related spending? Table 3 shows that part of the financing came from domestic borrowing. Net claims on the central government, which records the transactions with the domestic banking system, indicated that government has in the past overdrawn balances in excess of its deposits with the banking system. The estimation shows that net claims on the central government as a percentage of GDP increase on average by 16 percent in the quarter immediately preceding an election. The post-election evidence also shows that the increases in net claims against the government are not reversed in the post-election period. Diagnostic tests indicate normality in the residuals and they allow rejection of the presence of heteroskedastic and autocorrelation. ${ }^{17}$

\section{Conclusions}

This paper presents evidence of opportunistic political business cycles in Papua New Guinea. In general, the above findings are consistent with the predictions of the rational opportunistic political models of Rogoff and Sibert (1988) and Rogoff (1990). The estimation results show a clear pattern of pre-election manipulation of fiscal instruments by incumbent governments - mainly increased development spending and overall primary expenditurefollowed in most cases by a retrenchment in the post-election period. The evidence also shows that credit to government increase in post-election years, as politicians seek some means of financing their election-year extravagance. A broader implication of these findings points to the potential incompatibility between the pressures motivating the political business cycles and ongoing efforts on economic and political reform, including the objective of longterm fiscal sustainability.

\footnotetext{
${ }^{16}$ Block (2002) has found similar results for African countries. The findings differ from the broader developing country results found in Shi and Svensson (2000).

17 The results were estimated by EVIEWS (version 5.1). The diagnostic tests have computer-generated probabilities (reported in Table 3 ) indicating the probability of accepting the null hypothesis of no model misspecification. The test for normality is the Jacque-Bera $\chi$ (2) test. Breusch-Godfrey serial correlation is a Lagrange Multiplier test of the hypothesis that the residuals of the regression are serially correlated. The test for heteroskadasticity is White's test (1980), which asymptotically follows a $\chi$ distribution, with degrees of freedom equivalent to the number of slope coefficients in the test regression.
} 


\section{REFERENCES}

Akhmedov, Akhmed and Ekaterina Zhuravskaya, 2004. "Opportunistic Political Cycles: Test in a Young Democracy Setting," Quarterly Journal of Economics, Vol.119, pp.130138 .

Alesina, Alberto and Jeffrey Sachs, 1988. "Political Parties and Business Cycle in the United States, 1948-1984," Journal of Money, Credit, and Banking, Vol. 20, pp. 63-82.

Alesina, Alberto, Nouriel Roubini and Gerald Cohen, 1997. Political Cycles and the Macroeconomy, (MIT Press, Cambridge, Mass.).

Ames, Barry, 1987. Political Survival: Politicians and Public Policy in Latin America, (UCB Press, Berkeley, Calif.).

Block, Steven, 2001. "Elections, Electoral Competitiveness, and Political Budget Cycles in Developing Countries," CID Working Paper No. 78, Harvard University.

Block, Steven, 2002. "Political Business Cycles, Democratization, and Economic Reform: The Case of Africa," Journal of Development Economics, Vol. 67, pp.205-228.

Drazen, Allan, 2001. “The Political Business Cycle After 25 Years," NBER Macroeconomics Annual 2000, (MIT Press, Cambridge, Mass.).

Frey, Bruno and Friedrich Schneider, 1978. "A Politico-Economic Model of the United Kingdom,” Economic Journal, Vol. 88, pp. 243-253.

Gonzalez, Maria, 2002. "Do Changes in Democracy Affect the Political Budget Cycle? Evidence from Mexico," Review of Development Economics, Vol. 6, pp. 204-24.

Hibbs, Douglas, 1977. "Political Parties and Macroeconomic Policy," American Political Science Review, Vol. 71, pp. 1467-87.

Khemani, Stuti, 2004. "Political Cycles in a Developing Economy: Effect of Elections in the Indian States," Journal of Development Economics Vol. 73, pp. 125-54.

Lijphart, Arend, 1999. Patterns of Democracy: Government Forms and Performance in 36 Countries. (Yale University Press, New Haven, Conn.).

Lindbeck, Assar, 1976. "Stabilization Policies in Open Economies with Endogenous Politicians," American Economic Review Papers and Proceedings, Vol. 66, pp. 1-19. 
Moyo, Dambisa, 1999. "The Determinants of Public Savings in Developing Countries," Working Paper, Oxford University.

Nordhaus, William, 1975. "The Political Business Cycle," Review of Economic Studies, Vol. 42, pp. 169-90.

Okole, Henry, 2004. "Westminster Practices in Papua New Guinea: Governance in a Melanesian State," Paper presented at the Political Culture, Representation, and Electoral Systems Conference, Port Vila, Vanuatu. July 2004.

Okole, Henry, 2005. "Papua New Guinea's Brand of Westminster: Democratic Traditions Overlaying Melanesian Cultures," Westminster Legacies: Democracy and Responsible Government in Asia, Australasia, and the Pacific, Haig Patapan, John Wanna, and Patrick Weller, eds. (UNSW Press, Sydney).

Persson, Torsten, Gerard Roland and Guido Tabellini, 2004. "How Do Electoral Rules Shape Party Structures, Government Coalitions, and Economic Policies," CEPR Discussion Paper No. 4226.

Persson, Torsten and Guido Tabellini, 2003. "Do Electoral Cycles Differ Across Political Systems?” Working Paper 232, IGIER, University of Bocconi.

Reilly, Ben, 2000. "Democracy, Ethnic Fragmentation, and Internal Conflict: Confused Theories, Faulty Data, and the 'Crucial Case' of Papua New Guinea," International Security, Vol. 25, pp.162-85.

Rogoff, Kenneth, 1990.“Equilibrium Political Budget Cycles,” American Economic Review, Vol. 80, pp. 21-36.

Rogoff, Kenneth and Anne Sibert, 1988. "Elections and Macroeconomic Policy Cycles," Review of Economic Studies, Vol. 55, pp.1-16.

Shi, Min and Jakob Svensson, 2000. "Political Business Cycles in Developed and Developing Countries," Development Research Group, (World Bank, Washington D.C.). 